UDC 620.91:519.863+519.854.3

\author{
V.V. Romanuke* \\ Polish Naval Academy, Gdynia, Poland \\ *corresponding author: romanukevadimv@gmail.com
}

\title{
ITERATIVE POWER MAXIMIZATION BY ONE-HALF COST DICHOTOMY FOR OPTIMIZING WIND FARM DEPLOYMENT
}

Background. In deploying a wind farm, it is important to hold a balance of energy generated by wind turbines and costs spent on buying and installing them. However, ranking the energy and costs is commonly uncertain. Besides, the existing methods of optimal wind farm deployment are pretty slow, whereas even optimal numbers of wind turbines of certain types along with their costs and energy produced by them may need to be frequently recalculated.

Objective. The goal is to develop a practically rapid method of maximizing the produced energy by minimizing the costs. The method should get rid of ranking the energy and costs. Besides, it should speed up the process of finding optimal numbers of wind turbines. The optimality here is to be interpreted in wide sense implying also fitting wind statistics, controlling the costs and production, and adjusting to energy markets.

Methods. Once an expected power for every wind turbine type is calculated, a power maximization problem is formulated in the form of an integer linear programming problem, where optimal numbers of wind turbines of certain types are to be found. This problem involves a span of acceptable annual energy formed by a maximum and a minimum of the annual desired energy. Additionally, costs are constrained. The minimal and maximal numbers of wind turbines of a definite type are constrained also. First, the power maximization problem is solved by an arbitrary large constraining costs. Then the constraining costs are decreased until the solution is nonempty. If the solution is empty, the costs are increased. Every next step of either the decrement or increment is twice smaller than the previous one. This process is continued until the change in the costs becomes sufficiently insignificant.

Results. The optimization process is rapidly executed requiring only a few iterations to achieve an optimal solution. In particular, solving optimization problems with five known wind turbine types takes up to one tenth of a second, so a bunch of such problems is solved within a second or so. In general, the optimization requires no less than 3 iterations. After the first iteration, the constraining costs drop too low and the problem has no solution. However, the empty solution at the third iteration is not excluded, and a nonempty solution can appear after a few empty solutions. Nevertheless, an apparent economical impact after applying the wind farm deployment optimization is expectedly strong. There is an example with saving almost 18.4 million euros, which is $28.2 \%$ of the initial (non-optimized) costs. Such gains, however, are expectedly decreasing as the relative difference between a maximum and a minimum of the annual desired energy is shortened.

Conclusions. The presented approach is a method of successive optimization. It allows to avoid solving the twocriterion problem for simultaneous energy maximization and cost minimization for deploying wind farms. The computational core of this method is that the expected power output is maximized via solving an integer linear programming problem. The successive optimization process starting with an initial power maximization problem by arbitrary large costs is always convergent if the problem has a nonempty solution. The costs then are dichotomized in order to produce energy between definite maximum and minimum so that further changes in costs would be ineffective. The dichotomization allows to rapidly achieve the optimal solution, which includes the final resulting annual energy, costs spent on it, and the respective numbers of wind turbine types to be installed.

Keywords: energy; costs; wind farm deployment; successive optimization; wind turbine; dichotomization; annual energy.

\section{Introduction}

Wind power is the most progressive renewable energy source, which has been intensively growing since early 2000s. This growth nearly reminds exponential one, and it is strongly believed to continue through the next decade [1,2]. The central place in the wind power technology is taken by wind farms whose task is to "capture" the wind power and convert it into electric energy. The con- verted energy must be transferable with a low loss factor [2, 3].

Deploying a new wind farm, situated in a new location, requires fulfilling a series of very important actions. First of all, wind statistics should be collected and analyzed. Independently of this, energetic needs are assessed letting know thus an annual energy, which is desired to be obtained on the location. An economic analysis of the functioning wind farm is carried out also including 
costs of buying and installing wind turbines. Such an analysis requires knowing an exact number of wind turbines and their costs $[4,5]$.

It was shown in $[6,7]$ that energy generated by wind turbines having diverse power curves is the best way to achieve the highest performance of the wind farm. The power curve diversity is intentional to fit as ineffectiveness of the single wind turbine against wind statistics, as well as to fit wind speed distribution uncertainty. For this, an algorithm of simultaneously maximizing the produced energy and minimizing the costs was suggested $[6,7]$. By the algorithm, the respective two-criterion problem is solved with an efficient solution (to a singlecriterion problem). The output of the algorithm is a set of wind turbine types, which should be bought and installed, and a respective set of numbers of wind turbines in every type [8].

However, such a solution has three difficulties. Firstly, the ranks of energy criterion and cost criterion are presumed to be equal. This is not always true, especially for terrains where the wind power technology is just at its beginning and minimization of costs is more important than maximization of energy [9]. Secondly, uncertainty of the parameters of wind statistics (i.e., a wind speed distribution) cannot be completely removed. Finding the guaranteed and expected values of the costs and the wind farm power outputs, as it is proposed in [7], makes nonetheless the optimization efficiency weaker [10]. And, finally, what partially relates to the second difficulty is that there is no fast way for recalculating the wind farm deployment parameters. Indeed, volatility of the wind speed distribution parameters along with volatility of wind turbine market pricing both necessitate an intensive series of recalculations before a trade-off is made $[4,10]$.

\section{Problem statement}

Despite the algorithm stated in [6, 7] allows optimizing wind farm energy and costs simultaneously, its practical implementation requires further development. Namely, optimal numbers of wind turbines of certain types along with their costs and energy produced by them may need to be frequently recalculated. Such recalculations may be needed even after the wind farm is already deployed and functions but either wind conditions or energy demands start changing, or both them differ from those previously embedded into the wind farm model before its deployment. Therefore, the goal is to develop a practically rapid method of maximiz- ing the produced energy by minimizing the costs. The method should get rid of ranking the energy and costs. In fact, it is going to be a contribution to wind farm deployment optimization by speeding up the process of finding optimal numbers of wind turbines. Nevertheless, the optimality here is to be interpreted in wide sense implying also fitting wind statistics, controlling the costs and production, and adjusting to energy markets.

\section{Wind statistics}

Apart from wind turbine types and their numbers, an average wind power capacity strongly depends on wind speed distribution of an area, whereon a wind farm is projected. It is commonly modeled as the Weibull distribution of wind speed $s[2,3,6,7]$ :

$$
p(s)=\frac{b}{a} \cdot\left(\frac{s}{a}\right)^{b-1} \cdot e^{-\left(\frac{s}{a}\right)^{b}} \text { by } s \in[0 ; \infty)
$$

with a positive shape parameter $b$ and a positive scale parameter $a$. The shape parameter relates to a factual range of wind speeds, whereas the scale parameter corresponds to the mean wind speed. These parameters of wind speed distribution (1) cannot be assessed as point estimates. They are commonly assessed as interval estimates, although the intervals are relatively pretty narrow. Besides, there are no probabilistic measures over those intervals as eliciting them from the observed wind statistics leads to uncertainty among a continuum of probabilistic measures over an interval. Being preliminarily assessed prior to the wind farm deployment, the parameters of wind speed distribution (1) are then determined more accurate after the wind farm starts its functioning.

\section{Initial parameters of wind farm deployment}

Let $K$ be a number of available wind turbine types. Denote the power curve of the $k$-th wind turbine type by $w(k, s) \quad(k=\overline{1, K})$, where $w(k, s)$ by a fixed wind speed is a power in megawatts (MW) produced by turbine $k$ at that speed. An expected power produced by the $k$-th wind turbine type is

$$
\rho_{k}=\int_{0}^{\infty} p(s) w(k, s) d s
$$

with using wind speed distribution (1) or other. 
Let $E_{\max }$ be an annual desired energy given in MWh. Then the respective expected power output in MW is $[1,7]$

$$
r_{\text {max }}=\frac{E_{\max }}{365.25 \cdot 24}=\frac{E_{\max }}{8766} .
$$

Obviously, energy level $E_{\max }$ cannot be always exactly achieved, so a lower value of the annual desired energy is given: it is $E_{\min }$, where $E_{\min }<E_{\max }$. In most practical cases, lower energy level $E_{\min }$ is about $90 \%$ of $E_{\max }$ or greater. The difference between $E_{\max }$ and $E_{\min }$ includes an amount of energy which can be spared.

Let an amount of financial resources required for a wind farm deployment be $C_{\max }$. These are maximal costs which can be spent on it. They include costs of buying and installing wind turbines. Thus, denote the costs for buying and installing the $k$-th wind turbine type by $v_{\text {buy }}^{(k)}$ and $v_{\text {ins }}^{(k)}$, respectively. For definiteness, may the costs be expressed in millions of euro.

\section{Power maximization problem}

In general, a wind farm is built of wind turbines of various types $[3,6,7]$. Thus, let $n_{k}$ be a number of wind turbines of type $k$, where $n_{k} \in \mathbb{N} \cup\{0\}$. In particular, this means that, by $n_{k}=0$, a wind farm is projected without wind turbines of type $k$. farm is

An expected power output of the entire wind

$$
\rho_{\Sigma}=\sum_{k=1}^{K} n_{k} \rho_{k}=\sum_{k=1}^{K} n_{k} \int_{0}^{\infty} p(s) w(k, s) d s .
$$

This power output costs

$$
C_{\Sigma}=\sum_{k=1}^{K} n_{k}\left(v_{\text {buy }}^{(k)}+v_{\text {ins }}^{(k)}\right) .
$$

Therefore, power (4) is to be maximized along with minimizing costs (5) by the following constraints.

Firstly, power (4) should not exceed maximum (3), nor should it be less than

$$
r_{\min }=\frac{E_{\min }}{8766},
$$

i. e.

$$
r_{\min } \leq \sum_{k=1}^{K} n_{k} \rho_{k} \leq r_{\max } .
$$

Secondly, the financial resources are limited to $C_{\max }$ :

$$
\sum_{k=1}^{K} n_{k}\left(v_{\text {buy }}^{(k)}+v_{\text {ins }}^{(k)}\right) \leq C_{\max } .
$$

Thirdly, a maximal number of wind turbines $N_{\max }$ exists, which is determined by the area, whereon a wind farm is projected. This factually is a geographic capacity of the area that is tightly connected to a reasonable and efficient geographic concentration of wind turbines. Thus, the total number of wind turbines is limited to $N_{\max }$ :

$$
\sum_{k=1}^{K} n_{k} \leq N_{\max } .
$$

Another peculiar constraint, which supplements constraint (9), is that a maximal number of wind turbines of a definite type may be limited also. Besides, a minimal number of wind turbines of that type may exists, which must be necessarily bought being imposed by, e.g., a contract binding the wind farm projector and a supplier of wind turbines. So,

$$
n_{k}^{(\min )} \leq n_{k} \leq n_{k}^{(\max )} \text { for } k=\overline{1, K}
$$

by a formal inequality

$$
0 \leq n_{k}^{(\min )} \leq n_{k}^{(\max )} \leq N_{\max } \text { for } k=\overline{1, K} .
$$

The described maximization problem, without yet considering minimization of costs (5), can be written as an integer linear programming problem. Let

$$
\mathbf{N}=\left[n_{k}\right]_{1 \times K}
$$

be a vector of unknown integers along with known vectors

$$
\mathbf{N}_{\min }=\left[n_{k}^{(\min )}\right]_{1 \times K} \text { and } \mathbf{N}_{\max }=\left[n_{k}^{(\max )}\right]_{1 \times K}
$$

of integers in inequalities (11). Consider a matrix

$$
\mathbf{A}=\left[a_{j k}\right]_{4 \times K}
$$

by

$$
a_{1 k}=\rho_{k}, \quad a_{2 k}=-\rho_{k}, a_{3 k}=v_{\text {buy }}^{(k)}+v_{\text {ins }}^{(k)}, a_{4 k}=1,
$$

and a vector-column 


$$
\mathbf{B}=\left[\begin{array}{llll}
r_{\max } & -r_{\min } & C_{\max } & N_{\max }
\end{array}\right]^{\mathrm{T}} .
$$

Then the integer linear programming problem is

$$
\max _{n_{k}, k=1, K} \sum_{k=1}^{K} n_{k} \rho_{k}
$$

subject to:

$$
\begin{gathered}
\mathbf{A N}^{\mathrm{T}} \leq \mathbf{B}, \\
\mathbf{N}_{\min } \leq \mathbf{N} \leq \mathbf{N}_{\text {max }}, \\
\mathbf{N} \in\{\mathbb{N} \cup\{0\}\}^{K} .
\end{gathered}
$$

Note that constraint (20) is required to be attached to inequality (19) for ensuring that all the $K$ variables in vector (12) be integers.

\section{Wind farm deployment optimization}

First, problem (17) subject to constraints (18)-(20) is solved by an arbitrary large $C_{\max }$. Denote such a solution by

$$
\mathbf{N}^{*}=\left[n_{k}^{*}\right]_{1 \times K} .
$$

The respective costs, according to (5), are

$$
C_{0}=\sum_{k=1}^{K} n_{k}^{*}\left(v_{\text {buy }}^{(k)}+v_{\text {ins }}^{(k)}\right) \text {. }
$$

The idea behind getting rid of ranking the energy and costs is quite simple. Starting off (21), the costs are decreased until the solution of problem (17) subject to constraints (18)-(20) is nonempty. Every next step of the decrement is smaller than the previous one. If the energy maximization problem has no solution, the costs are increased. Every next step of the increment is smaller likewise than the previous one. This process is continued until the change in the costs (either decrement or increment) becomes sufficiently insignificant. Then the last nonempty solution of the energy maximization problem is saved and considered as the optimal one for the wind farm deployment. The iterative process can be organized with using a simple dichotomization approach [11]. Therefore, once solution (21) is found, problem (17) subject to constraints $(18)-(20)$ is further solved as follows.

Value $\delta=1$ is initially set along with some integer $Q$. This integer defines a maximal number of energy maximization problems to be solved, including the initial problem with solution (21). After solution (21) is found, the new constraining costs into vector (16) are set: $C_{\max }=C_{0}$. The iterative process is continued while $\delta>1 / 2^{Q}$. After the next energy maximization problem is solved, the change in the costs is twice reduced:

$$
\delta^{(\mathrm{obs})}=\delta \text { and } \delta=\delta^{(\mathrm{obs})} / 2 .
$$

If a solution of problem (17) subject to constraints (18)-(20) is nonempty, then

$$
C_{\max }^{\text {(obs) }}=C_{\max } \text { and } C_{\max }=C_{\max }^{\text {(obs) }}-\delta C_{0} .
$$

Otherwise, if the solution is empty, then

$$
C_{\max }^{(\text {obs })}=C_{\max } \text { and } C_{\max }=C_{\max }^{(\text {obs })}+\delta C_{0} .
$$

Denote the nonempty solution of the $q$-th problem by

$$
\mathbf{N}^{*}(q)=\left[n_{k}^{*}(q)\right]_{1 \times K}(q=\overline{1, Q}),
$$

where $\mathbf{N}^{*}(1)=\mathbf{N}^{*}$. Besides, denote the expected power output of the entire wind farm by $\rho_{\Sigma}(q)$ corresponding to the annual energy

$$
E(q)=8766 \cdot \rho_{\Sigma}(q),
$$

and denote this power output costs by $C_{\Sigma}(q)$, where $C_{\Sigma}(1)=C_{0}$.

Consider an example related to one example in [6], wherein $b=2, a=5$ (which corresponds to the mean wind speed $4.43 \mathrm{~m} / \mathrm{s})$. A wind farm is projected on the base of five $(K=5)$ known and widespread wind turbines [7]:

1. Enercon E82 E2 (2.3 MW).

2. Gamesa G128-4.5 MW.

3. Nordex N90/2500 (2.5 MW).

4. REpower MM82 (2 MW).

5. Vestas V112-3.0 MW.

The prices for buying and installing these wind turbines are pretty volatile. So, they can be only roughly estimated. Thus, having enumerated the turbines from $\# 1$ to $\# 5$, respectively, their costs in millions of euro are:

$$
\begin{gathered}
v_{\text {buy }}^{(1)}=3.1, v_{\text {buy }}^{(2)}=7.72, \\
v_{\text {buy }}^{(3)}=3.25, v_{\text {buy }}^{(4)}=2.68, v_{\text {buy }}^{(5)}=5.1,
\end{gathered}
$$

and

$$
\begin{gathered}
v_{\text {ins }}^{(1)}=0.277729, v_{\text {ins }}^{(2)}=1.72239376, \\
v_{\text {ins }}^{(3)}=0.30525625, v_{\text {ins }}^{(4)}=0.20757136, \\
v_{\text {ins }}^{(5)}=0.751689,
\end{gathered}
$$


where $[6,7]$

$$
v_{\text {ins }}^{(k)}=\left(0.17 v_{\text {buy }}^{(k)}\right)^{2} \text { for } k=\overline{1,5} .
$$

The annual desired energy is $E_{\max }=17500 \mathrm{MWh}$, whereas $E_{\min }=15750 \mathrm{MWh}$ (it is $90 \%$ of the maximum). Let the total number of wind turbines be limited to 25 regardless of the wind turbine types. Therefore, inequality (7) is

$$
1.79671458 \leq \sum_{k=1}^{5} n_{k} \rho_{k} \leq 1.99634953,
$$

where

$$
\begin{aligned}
& \rho_{1}=0.24448531, \\
& \rho_{2}=0.7114002, \\
& \rho_{3}=0.26110028, \\
& \rho_{4}=0.22377591, \\
& \rho_{5}=0.26336238 .
\end{aligned}
$$

Setting $C_{\max }=1000$ (being sufficiently large here), inequality $(8)$ is

$$
\begin{gathered}
3.377729 n_{1}+9.44239376 n_{2}+3.55525625 n_{3} \\
+2.88757136 n_{4}+5.851689 n_{5} \leq 1000,
\end{gathered}
$$

and inequalities (9) and (10) are

$$
\sum_{k=1}^{5} n_{k} \leq 25,0 \leq n_{k} \leq 25 \text { for } k=\overline{1,5} .
$$

Then, matrix (14) is determined by its already known elements (15), and vector-column (16) is determined as well. Now, problem

$$
\max _{n_{k}, k=1,5} \sum_{k=1}^{5} n_{k} \rho_{k}
$$

subject to constraints $(18)-(20)$, which are formed by inequalities (28)-(30), is solved. The initial solution is

$$
\mathbf{N}^{*}=\mathbf{N}^{*}(1)=\left[n_{k}^{*}(1)\right]_{1 \times 5}=\left[\begin{array}{lllll}
6 & 0 & 0 & 0 & 2
\end{array}\right],
$$

wherein the respective costs by (22) are $C_{0}=31.969752$ allowing to achieve an expected power output in $1.99363663 \mathrm{MW}$, which corresponds to an annual energy in 17476.218682 MWh. Then, according to (23), $\delta=1 / 2$ and decrement (24) is executed (i.e., the new constraining costs herein become $\left.C_{\max }=15.984876\right)$. The whole process for eight iterations $(Q=8)$ is shown in Fig. 1,



Fig. 1. The process of eight iterations for wind farm deployment optimization, where the final resulting annual energy is $15874.4957616 \mathrm{MWh}$ (by the required minimum $15750 \mathrm{MWh})$, which costs 23.59072852 million euros, and $\mathbf{N}^{*}(8)=\left[n_{k}^{*}(8)\right]_{1 \times 5}=\left[\begin{array}{lllll}1 & 0 & 0 & 7 & 0\end{array}\right]$ (i. e., the wind farm should be built of 8 wind turbines one turbine Enercon and 7 turbines REpower; the coincidence of the iteration number with the total number of wind turbines is purely occasional) 
whereon the resulting annual energy and its costs for every empty solution are set at the preceding values. The cost bounds which, generally speaking, are

$$
C_{\Sigma}(Q) \pm C_{0} / 2^{Q},
$$

allow to relatively estimate the accuracy of the cost minimization. Bounds (32) "trap" the final resulting costs, and they do not necessarily "trap" constraining costs $C_{\max }$ at the final iteration. Compared to how this example was solved in [6], where the energy and costs were maximized and minimized simultaneously, the final resulting costs are decreased from 26.551 to 23.59072852 million euros (see Fig. 2). The difference is more than significant: by sustaining the required annual energy minimum, it is 2960271.48 euros. By the way, executing more than eight iterations in this example does not improve the obtained solution.

Another example with the twice greater annual desired energy, where the rest of parameters are the same, is shown in Fig. 3. It takes only six iterations to get the optimal annual energy and costs. It is noticeable that here the initial solution is

$$
\mathbf{N}^{*}=\mathbf{N}^{*}(1)=\left[n_{k}^{*}(1)\right]_{1 \times 5}=\left[\begin{array}{lllll}
3 & 1 & 3 & 2 & 5
\end{array}\right]
$$

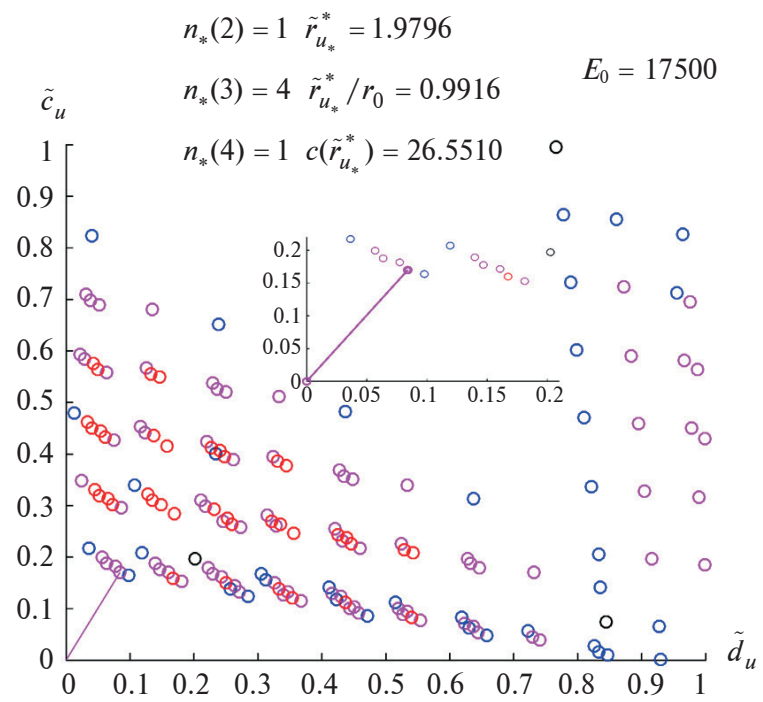

Fig. 2. The result of simultaneous energy maximization and cost minimization (see the copied Figure 1 in [6]) for the example in Fig. 1; by this version, the wind farm should have been built of 6 wind turbines - one turbine Gamesa, 4 turbines Nordex, and one turbine REpower (despite the annual energy in $17353.1736 \mathrm{MWh}$, this version is almost 3 million euros more expensive than that in Fig. 1) implying that the wind farm would be built of 14 wind turbines involving each of those five wind turbine types. Such a solution ensuring an annual energy in $34998.436412 \mathrm{MWh}$ (which is $99.9955 \%$ of the maximum) would cost 65.27493723 million euros, which is 18.40611058 million euros more expensive than the optimal costs in 46.86882665 million euros. So, this is an example of that the suggested optimization process can have a really great positive impact on the wind farm deployment. On the other hand, this exemplifies that the most profitable deployment does not always imply a great diversity of wind turbine types. The wind farm here is optimally deployed by two types of wind turbines, whereas solution (33) stands for involving five types. The fact that the optimized wind farm consists of two wind turbines more can seemingly be a trade-off.

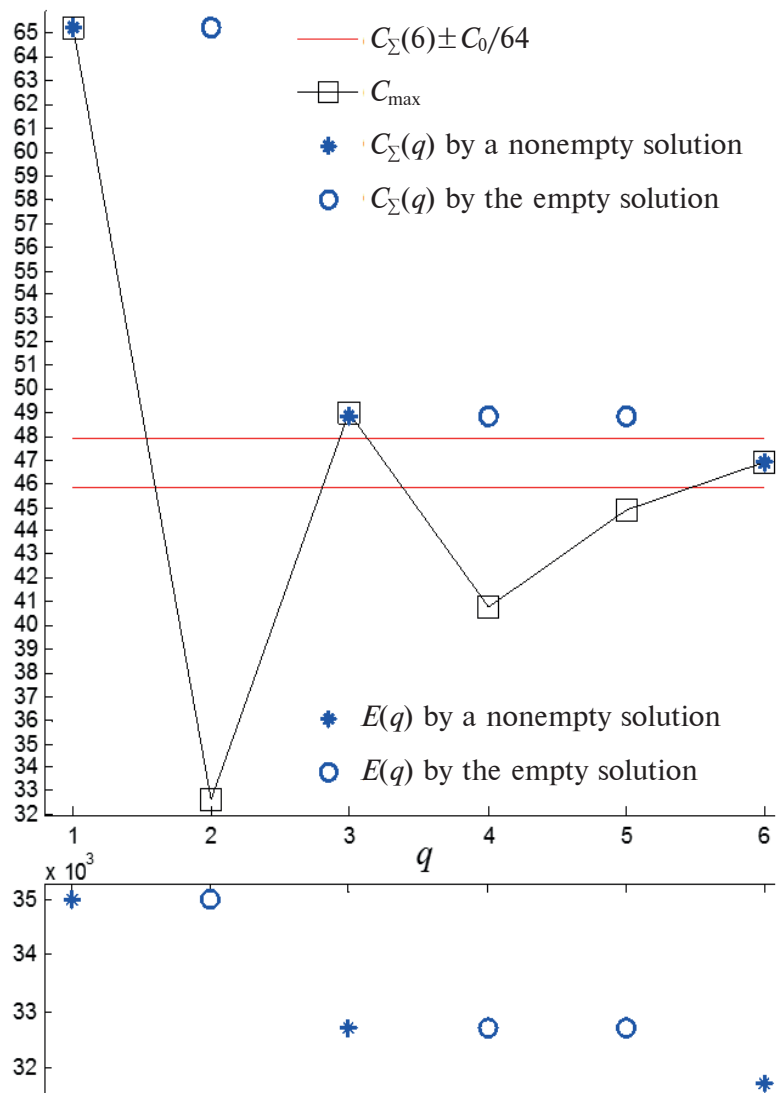

Fig. 3. The process of six iterations for wind farm deployment optimization, where the final resulting annual energy is $31713.099738 \mathrm{MWh}$ (by the required minimum $31500 \mathrm{MWh}$ ), which costs 46.86882665 million euros, and $\mathbf{N}^{*}(6)=\left[n_{k}^{*}(6)\right]_{1 \times 5}=\left[\begin{array}{lllll}0 & 0 & 1 & 15 & 0\end{array}\right]$ (i. e., the wind farm should be built of 16 wind turbines - one turbine Nordex and 15 turbines REpower) 
Other numerical experiments show (Fig. 4) that the polyline of changes in $C_{\max }$ resembles those ones in Figs. 1 and 3. Every iterative optimization process is convergent, although there are always many empty solutions. The only condition of a correct start is to obtain a nonempty solution
(21) of the initial problem. This can be sometimes an uneasy task due to minimal power output (6) may be required and correspondingly set at a higher rate.

It is also clear that the optimization process must have iterations with empty solutions. Such it-
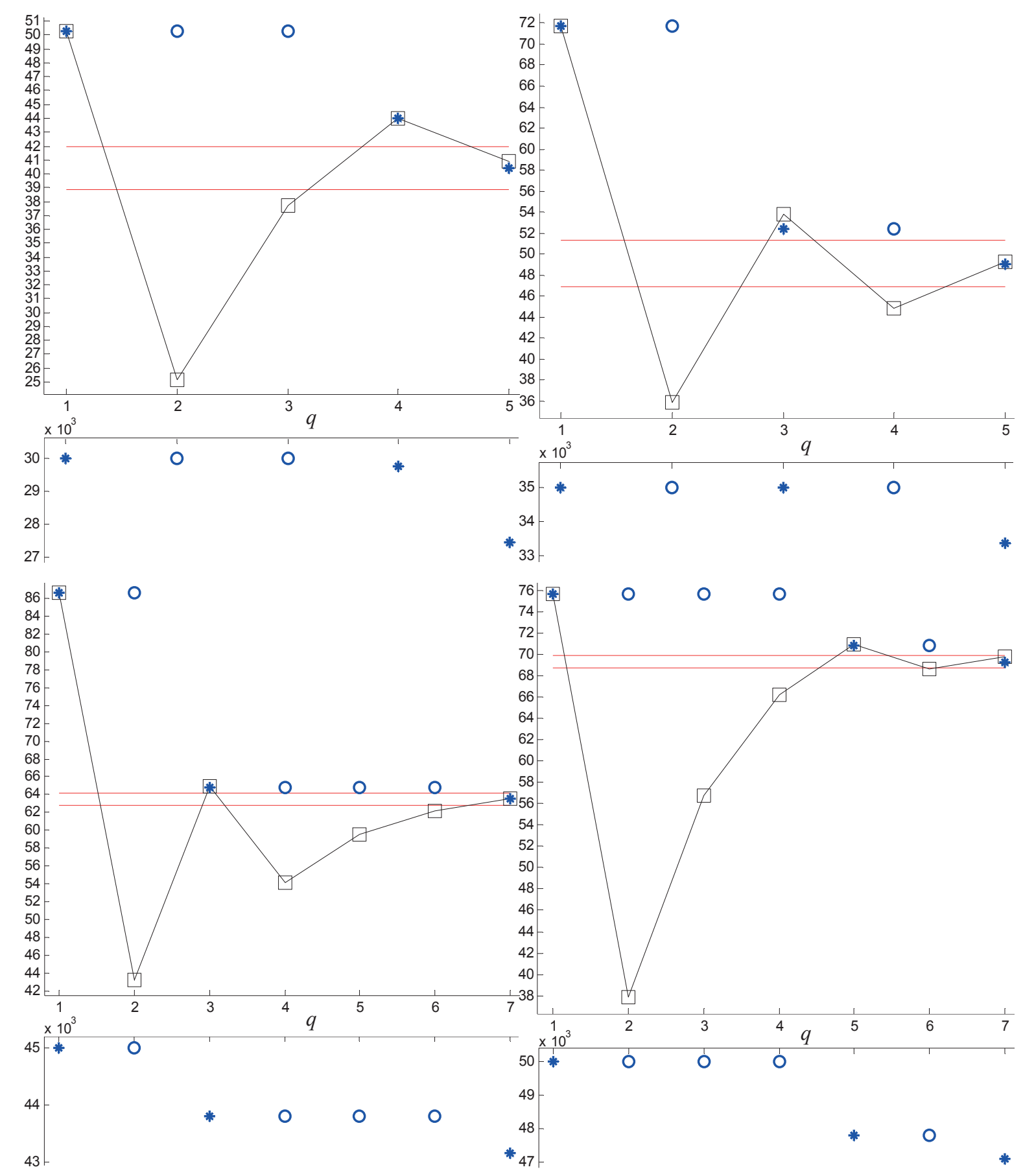

Fig. 4. A series of four additional examples, showing that an optimal solution is achieved in just a few iterations, where every polyline of the constraining costs (with squared points) is depressed similarly to those ones in Figs. 1 and 3 
erations, whose number can be even greater than the number of iterations with nonempty solutions, are unavoidable. This and other peculiarities of the suggested iterative optimization are to be discussed below.

\section{Discussion}

To start the optimization, apart from expected power (2) for every wind turbine type, $E_{\max }$, $E_{\min }$, and the costs for buying and installing every wind turbine type, it is also compulsory to enter integer $Q$. These parameters are required without exceptions. The rest of the constraining parameters, if they do not have special requirements, can be set loose just like inputting an arbitrary large $C_{\max }$ for the initial problem: number $N_{\max }$ and elements of vector $\mathbf{N}_{\max }$ are made arbitrary large, whereas all elements of vector $\mathbf{N}_{\text {min }}$ are set at 0 . Special attention must be paid to calculation of expected powers $\left\{\rho_{k}\right\}_{k=1}^{K}$, which strongly depend on the wind speed distribution parameters and representation accuracy of wind turbine power curves $[12,13]$. The expected power is indeed very sensitive to the shape and scale parameters, so their inaccurate determination may badly bias an optimal solution if even the power curves are all represented accurately.

Vectors (13) for constraints (19) should be determined carefully as well, but any inexactnesses in their elements are easily corrected by recalculations, which are rapidly executed by the suggested successive optimization process. If some parameters concerning a functioning wind farm change, the rapid recalculation by a set of adjusted parameters will give a solution $\mathbf{N}^{*}(Q)$ prompting which type and how many wind turbines are to be turned off/on. Other needs for the recalculation may emerge from volatility of the prices for buying and installing wind turbines. The example of that installing prices (27) are tied to buying prices (26) is just a naive pattern. So, the rapid recalculation of the optimal solution by the suggested successive optimization excellently fits such situations. In particular, solving optimization problems like that with objective (31) takes up to one tenth of a second, so a bunch of such problems is solved within a second or so.

It is easy to see that the optimization requires no less than 3 iterations. After the first iteration, the constraining costs drop too low and the problem has no solution. Then, at the third iteration, the constraining costs are increased according to (25), where $\delta=1 / 4$. So, this "triangle" turned over with its middle vertex downward is a distinct feature of the optimization process. However, the empty solution at the third iteration is not excluded (see Fig. 4). This nonetheless is normal, because a nonempty solution (in which the resulting costs are lower) can appear after a few empty solutions (see it in Fig. 1, wherein the final nonempty solution appears after four iterations with empty solutions).

An apparent economical impact after applying the wind farm deployment optimization is expectedly strong. The example with saving almost 18.4 million euros (Fig. 3), which is $28.2 \%$ of the initial (non-optimized) costs, is quite remarkable. Such gains, however, are expectedly decreasing as the relative difference between a maximum and a minimum of the annual desired energy is shortened.

\section{Conclusions}

An optimization approach, presented in this paper, allows to avoid solving the two-criterion problem for simultaneous energy maximization and cost minimization for deploying wind farms. As solving the two-criterion problem is partially uncertain due to not surely known priority relationship between energy demands and financial resources, the presented approach is a method of successive optimization. The computational core of this method is that the expected power output is maximized via solving an integer linear programming problem. The successive optimization process starting with an initial power maximization problem by arbitrary large costs is always convergent if the problem has a nonempty solution. The costs then are dichotomized in order to produce energy between definite maximum and minimum so that further changes in costs would be ineffective. The dichotomization allows to rapidly achieve the optimal solution, which includes the final resulting annual energy, costs spent on it, and the respective numbers of wind turbine types to be installed.

A promising way to improve the suggested optimization process is to consider dichotomization steps different from one-half. This must be tried along with tolerating non-fixed parameters of the wind speed distribution. Despite it is not obvious that an improvement will be significant, such a supplement to the suggested successive optimization will be a more complete contribution to the theory and practice of wind farm deployment. 


\section{References}

[1] P. Breeze, "Wind power", in Power Generation Technologies, 3rd ed., P. Breeze, Ed. Newnes, 2019, ch. 11, pp. $251-273$. doi: 10.1016/B978-0-08-102631-1.00011-0

[2] B.H. Bailey, "Wind resources for offshore wind farms: Characteristics and assessment", in Offshore Wind Farms, C. Ng, L. Ran, eds. Woodhead Publishing, 2016, pp. 29-58. doi: 10.1016/B978-0-08-100779-2.00003-9

[3] Wind Energy Engineering. A Handbook for Onshore and Offshore Wind Turbines, T.M. Letcher, Ed. Elsevier, Academic Press, 2017, 622 p.

[4] P.E. Morthorst and L. Kitzing, "Economics of building and operating offshore wind farms", in Offshore Wind Farms, C. Ng, L. Ran, eds. Woodhead Publishing, 2016, pp. 9-27. doi: 10.1016/B978-0-08-100779-2.00002-7

[5] M. Santos and M. González, "Factors that influence the performance of wind farms", Renewable Energy, vol. 135, pp. 643651, 2019. doi: 10.1016/j.renene.2018.12.033

[6] V.V. Romanuke, "Wind farm deployment by wind turbines of different power curves under a 2-way routine of energy-andcosts constrained optimization", Bulletin of V. Karazin Kharkiv National University. Series "Mathematical Modelling. Information Technology. Automated Control Systems”, iss. 39, pp. 69-75, 2018.

[7] V.V. Romanuke, "Wind farm energy and costs optimization algorithm under uncertain parameters of wind speed distribution”, Studies in Informatics and Control, vol. 27, iss. 2, pp. 155-164, 2018. doi: 10.24846/v27i2y201803

[8] G. Gualtieri, "A novel method for wind farm layout optimization based on wind turbine selection", Energy Conversion and Management, vol. 193, pp. 106-123, 2019. doi: 10.1016/j.enconman.2019.04.059

[9] A.C. Kheirabadi and R. Nagamune, "A quantitative review of wind farm control with the objective of wind farm power maximization", J. Wind Engineering and Industrial Aerodynamics, vol. 192, pp. 45-73, 2019. doi: 10.1016/j.jweia.2019.06.015

[10] A. Chehouri et al., "Review of performance optimization techniques applied to wind turbines", Appl. Energy, vol. 142, pp. 361-388, 2015. doi: 10.1016/j.apenergy.2014.12.043

[11] V.V. Romanuke, "Interval uncertainty reduction via division-by-2 dichotomization based on expert estimations for shorttermed observations", J. Uncertain Systems, vol. 12, no. 1, pp. 3-21, 2018.

[12] V.V. Romanuke, "Wind turbine power curve exponential model with differentiable cut-in and cut-out parts", KPI Sci. News, no. 2, pp. 33-43, 2018. doi: 10.20535/1810-0546.2018.2.121504

[13] T. Ouyang et al., "Modeling wind-turbine power curve: A data partitioning and mining approach", Renewable Energy, vol. 102, part A, pp. 1-8, 2017. doi: 10.1016/j.renene.2016.10.032

\section{В.В. Романюк}

\section{ІТЕРАЦІЙНА МАКСИМІЗАЦІЯ ПОТУЖНОСТІ ЗА ПОЛОВИННОЇ ДИХОТОМІЇ ВИТРАТ ДЛЯ ОПТИМІЗАЦІЇ РОЗГОРТАННЯ ВІТРОВОЇ ЕЛЕКТРОСТАНЦІї}

Проблематика. При розгортанні вітрової електростанції дуже важливо утримувати баланс енергії, генерованої вітровими турбінами, та витрат на їх купівлю і монтування. Однак ранжування енергії та витрат є зазвичай невизначеним. Крім того, існуючі методи оптимального розгортання вітрової електростанції є доволі повільними, тоді як навіть оптимальні кількості вітрових турбін певних типів разом із їх вартостями та виробленою енергією можуть потребувати частого перерахунку.

Мета дослідження. Метою є побудова практично швидкісного методу максимізації виробленої енергії за мінімізації витрат. Цей метод має позбутися залежності від ранжування енергії та витрат. Крім того, він повинен прискорити процес визначення оптимальних кількостей вітрових турбін. Оптимальність тут розуміється в широкому смислі, включаючи також припасування до статистики вітрів, контроль витрат і виробництва, адаптацію до енергетичних ринків.

Методика реалізації. По обчисленні очікуваної потужності для вітрової турбіни кожного типу формулюється задача максимізації потужності у формі задачі цілочислового лінійного програмування, у якій мають бути визначені оптимальні кількості вітрових турбін визначених типів. Ця задача включає проміжок прийнятної щорічної енергії на основі максимуму та мінімуму щорічної бажаної енергії. Крім цього, обмежуються і витрати. Мінімальні та максимальні кількості вітрових турбін визначених типів обмежуються також. Спочатку задача максимізації потужності розв'язується за як завгодно великих обмежувальних витрат. Далі обмежувальні витрати зменшуються доти, доки розв'язок не стане порожнім. Якщо розв'язок є порожнім, ці витрати збільшуються. На кожному наступному кроці таке зменшення або збільшення є вдвічі меншим, ніж воно було на попередньому. Цей процес продовжується до тих пір, доки зміна витрат не стане достатньо незначною.

Результати дослідження. Такий процес оптимізації виконується напрочуд швидко, вимагаючи лише кількох ітерацій для того, щоб досягти оптимального розв'язку. Зокрема, розв'язування задач оптимізації з п'ятьома відомими типами вітрових турбін займає до однієї десятої секунди, так що група таких задач розв'язується за секунду або близько того. Взагалі ця оптимізація вимагає не менше ніж три ітерації. Після першої ітерації обмежувальні витрати падають занизько, і задача не має розв'язку. Однак порожній розв'язок на третій ітерації не виключений, і непорожній розв'язок може з'явитися після декількох порожніх розв'язків. Проте безсумнівний економічний вплив після застосування оптимізації розгортання вітрової електростанції $є$ очікувано потужним. Показано приклад із заощадженням майже 18,4 мільйона євро, що становить 28,2 \% від початкових (неоптимізованих) витрат. Однак очікується, що подібні прирости є спадними зі скороченням відносної різниці між максимумом та мінімумом щорічної бажаної енергії.

Висновки. Запропонований підхід є методом послідовної оптимізації. Він дає змогу уникнути розв'язування двокритеріальної задачі з одночасною максимізацією енергії та мінімізацією витрат для розгортання вітрових електростанцій. Обчислю- 
вальним ядром цього методу є те, що очікувана потужність максимізується у розв'язуванні задачі цілочислового лінійного програмування. Процес послідовної оптимізації, що починається з початкової задачі максимізації потужності за як завгодно великих витрат, завжди є збіжним, якщо така задача має непорожній розв'язок. Втрати потім дихотомізуються з метою виробляти енергію між визначеними максимумом і мінімумом так, щоб подальші зміни витрат були неефективними. Ця дихотомізація дає можливість швидко досягнути оптимального розв'язку, який включає результуючу щорічну енергію, витрати на неї, а також відповідні кількості типів вітрових турбін, що мають бути змонтовані.

Ключові слова: енергія; витрати; розгортання вітрової електростанції; послідовна оптимізація; вітрова турбіна; дихотомізація; щорічна енергія.

\section{В.В. Романюк}

\section{ИТЕРАЦИОННАЯ МАКСИМИЗАЦИЯ МОЩНОСТИ ПРИ ПОЛОВИННОЙ ДИХОТОМИИ ЗАТРАТ ДЛЯ ОПТИМИЗАЦИИ РАЗВЕРТЫВАНИЯ ВЕТРОВОЙ ЭЛЕКТРОСТАНЦИИ}

Проблематика. При развертывании ветровой электростанции очень важно удерживать баланс энергии, генерируемой ветровыми турбинами, и затрат на их покупку и монтирование. Однако ранжирование энергии и затрат обычно является неопределенным. Кроме того, существующие методы оптимального развертывания ветровой электростанции довольно медленные, тогда как даже оптимальные количества ветровых турбин определенных типов вместе с их стоимостями и произведенной энергией могут нуждаться в частом перерасчете.

Цель исследования. Целью является построение практически скоростного метода максимизации произведенной энергии при минимизации затрат. Этот метод должен избавиться от зависимости от ранжирования энергии и затрат. Кроме того, он должен ускорить процесс определения оптимальных количеств ветровых турбин. Оптимальность здесь понимается в широком смысле, включая также подгон к статистике ветров, контроль затрат и производства, адаптацию к энергетическим рынкам.

Методика реализации. После вычисления ожидаемой мощности для ветровой турбины каждого типа формулируется задача максимизации мощности в форме задачи целочисленного линейного программирования, в которой должны быть определены оптимальные количества ветровых турбин определенных типов. Эта задача включает промежуток приемлемой ежегодной энергии на основе максимума и минимума ежегодной желательной энергии. Кроме этого, ограничиваются и затраты. Минимальное и максимальное количества ветровых турбин определенных типов ограничиваются также. Сначала задача максимизации мощности решается при как угодно больших ограничивающих затратах. Дальше ограничивающие затраты уменьшаются до тех пор, пока решение не станет пустым. Если решение является пустым, эти затраты увеличиваются. На каждом следующем шаге такое уменьшение или увеличение является вдвое меньшим, чем оно было на предыдущем. Этот процесс продолжается до тех пор, пока изменение затрат не станет достаточно незначительным.

Результаты исследования. Такой процесс оптимизации выполняется крайне быстро, требуя лишь нескольких итераций для того, чтобы достичь оптимального решения. В частности, решение задач оптимизации с пятью известными типами ветровых турбин занимает до одной десятой секунды, так что группа таких задач решается за секунду или около того. Вообще эта оптимизация требует не меньше чем три итерации. После первой итерации ограничивающие затраты падают слишком низко, и задача не имеет решения. Однако пустое решение на третьей итерации не исключено, и непустое решение может появиться после нескольких пустых решений. Тем не менее несомненное экономическое влияние после применения оптимизации развертывания ветровой электростанции ожидаемо мощно. Показан пример со сбережением почти 18,4 миллиона евро, что составляет 28,2 \% от начальных (неоптимизированных) затрат. Однако ожидается, что подобные приросты являются убывающими при сокращении относительной разности между максимумом и минимумом ежегодной желательной энергии.

Выводы. Предложенный подход является методом последовательной оптимизации. Он позволяет избежать решения двухкритериальной задачи с одновременной максимизацией энергии и минимизацией затрат для развертывания ветровых электростанций. Вычислительным ядром этого метода является то, что ожидаемая мощность максимизируется в решении задачи целочисленного линейного программирования. Процесс последовательной оптимизации, которая начинается с начальной задачи максимизации мощности при как угодно больших затратах, всегда является сходящимся, если такая задача имеет непустое решение. Потери потом дихотомизируются с целью вырабатывать энергию между определенными максимумом и минимумом так, чтобы дальнейшие изменения затрат были неэффективными. Эта дихотомизация позволяет быстро достичь оптимального решения, которое включает результирующую ежегодную энергию, затраты на нее, а также соответствующие количества типов ветровых турбин, которые должны быть смонтированы.

Ключевые слова: энергия; затраты; развертывание ветровой электростанции; последовательная оптимизация; ветровая турбина; дихотомизация; ежегодная энергия.

Рекомендована Радою

факультету прикладної математики

КПІ ім. Ігоря Сікорського
Надійшла до редакції

20 травня 2019 року

Прийнята до публікації 05 вересня 2019 року 